\title{
Originals
}

\section{Effects of insulin-like growth factors (IGF) on pancreatic islet function in IGF binding protein-1 transgenic mice}

\author{
S.T. Dheen, K. Rajkumar, L. J. Murphy \\ Departments of Internal Medicine and Physiology, University of Manitoba, Winnipeg, Canada
}

\begin{abstract}
Summary We have previously reported fasting hyperglycaemia, hyperinsulinaemia, and glucose intolerance in transgenic $(\mathrm{Tg})$ mice which overexpress rat insulin-like growth factor binding protein-1 (IGFBP1). An increase in pancreatic islet size and number was also observed in this model. Islets from $\mathrm{Tg}$ mice had relatively more beta cells and less alpha cells than islets from wild-type (Wt) mice. These observations prompted us to investigate the effects of glucose and insulin-like growth factor-I (IGF-I) on insulin and glucagon release by isolated islets from $\mathrm{Tg}$ and Wt mice. Under basal glucose conditions, islets from $\mathrm{Tg}$ mice released significantly more insulin and less glucagon than islets from Wt mice. This difference was significant even when corrected for the increased size and cellularity of islets from $\mathrm{Tg}$ mice. A dose-dependent increase in insulin release was observed with increased glucose concentrations in both $\mathrm{Wt}$ and $\mathrm{Tg}$ mice. At all but the highest glucose concentration,
\end{abstract}

islets from $\mathrm{Tg}$ mice released significantly greater amounts of insulin than islets from Wt mice. Addition of IGF-I to islet incubations resulted in a dose-dependent increase in insulin release. However, the effect of IGF-I on islets from Tg mice was reduced compared to islets from Wt mice. From these data we conclude that IGF-I stimulates rather than inhibits insulin secretion in isolated murine islets. Furthermore, an intrinsic defect in pancreatic islet insulin release is not responsible for the glucose intolerance in $\mathrm{Tg}$ mice. Rather, the data suggest that the hyperglycaemia or local effects of IGFBP-1 over-expression results in a state of enhanced insulin secretion which persists under short-term in vitro culture conditions. [Diabetologia (1996) 39: 1249-1254]

Keywords Insulin-like growth factors, islets, transgenic mice, binding proteins.
Insulin-like growth factors (IGFs) are present in the circulation and the extracellular space bound to members of a family of high affinity insulin-like growth factor binding proteins (IGFBPs). To date, six IGFBPs, ranging in size from approximately 17 to

Received: 4 March 1996 and in revised form: 3 June 1996

Corresponding author: L. J. Murphy, MB PhD, Departments of Medicine and Physiology, University of Manitoba, Winnepeg R3E OW3, Canada

Abbreviations: Tg, Transgenic; Wt, wild-type; IGF, insulin-like growth factor; IGF-I and II, insulin-like growth factor-I and II; IGFBP, insulin-like growth factor binding protein; HBSS, Hanks Balanced Salt Solution; DNA, deoxyribonucleic acid; NGS, normal goat serum; BSA, bovine serum albumin.
$43 \mathrm{kDa}$, have been cloned and sequenced [1]. These binding proteins have been shown to be released by a variety of cell types and may either augment the actions of the IGFs or more commonly inhibit IGF actions [2]. Of the IGFBPs which have been shown to be present in the circulation, IGFBP-1, the first of these binding proteins to be isolated, may be the most important in regulating the insulin-like activity of the IGFs and in counter regulation [3,4]. Unlike the other IGFBPs present in the circulation the levels of IGFBP-1 fluctuate quite widely.

A potential role for IGFBP-1 in regulating the insulin-like activities of IGF-I and IGF-II is supported by the inverse regulation of IGFBP-1 by insulin [3]. Circulating levels of IGFBP-1 and hepatic expression of this binding protein are up-regulated in fasted rats 
and in streptozotocin-induced diabetic rats [5]. In man, IGFBP-1 levels are suppressed during oral glucose tolerance tests [6]. An observation which can be explained by transcriptional suppression of IGFBP1 mediated via the insulin response element in the $5^{\prime}$ flanking region of the IGFBP-1 gene [7]. In rats IGFBP-1 infusion causes mild hyperglycaemia suggesting that the small free component of the circulating IGFs has some hypoglycaemic action [4].

These previously reported observations, together with our recent report of fasting hyperglycaemia, fasting hyperinsulinaemia and impaired glucose tolerance in transgenic ( $\mathrm{Tg}$ ) mice which constitutively overexpress IGFBP-1 $[8,9]$ indicate that IGFBP1 may be important in glucose homeostasis. During the investigation of the hyperglycaemia in these $\mathrm{Tg}$ mice we noted an increase in the relative weight of pancreas and larger and more numerous pancreatic islets in $\mathrm{Tg}$ mice than the $\mathrm{Wt}$ mice derived from the same genetic background [9]. However, pancreatic insulin content was significantly reduced in the $\mathrm{Tg}$ mice compared to $\mathrm{Wt}$ mice. The present study was undertaken to investigate whether there is any alteration in secretion of insulin and glucagon from pancreatic islets in the Tg mice compared to Wt mice.

\section{Materials and methods}

Transgenic mice. Generation and characterization of the $\mathrm{Tg}$ mouse strains have been described in detail elsewhere [8]. Tg mice overexpressing IGFBP-1 were generated using rat genomic fragment containing the entire coding region of the IGFBP-1 gene including the 3 ' untranslated sequence, the 5 ' untranslated region and 78 base pairs (bp) of $5^{\prime}$ flanking DNA was inserted downstream of the mouse phosphoglycerate kinase promoter. For comparison, Wt mice were generated from non-transgenic offspring of founder mice of the same genetic background bred in a similar fashion to the $\mathrm{Tg}$ mice. Male mice of about 8 weeks of age were used for all experiments. The majority of studies were performed using the 277A strain of $\mathrm{Tg}$ mice; however, all three high expressing strains of IGFBP-1 Tg mice exhibit similar disturbances in glucose homeostasis [9]. All animal experiments were performed in accordance with protocols approved by the Animal Care Committee of the Faculty of Medicine, University of Manitoba.

Isolation of islets. Pancreatic islets were isolated from the pancreas of $\mathrm{Tg}$ and Wt mice by the method of Lacy and Kostianovsky [10]. The mice were anaesthetized with Avertin and the pancreases were distended by injection of $8 \mathrm{ml}$ Hanks Balanced Salt Solution (HBSS) through the common bile duct. Before the injection, the distal end of the common bile duct was clamped adjacent to the duodenum. Subsequently, the distended pancreas was removed, cleaned of fat, washed in three changes of HBSS and minced. The pancreatic tissue pieces were transferred to sterile tubes containing $5 \mathrm{mg} / \mathrm{ml}$ of collagenase (Type XI, Sigma Chemical Co., St. Louis Mo., USA) and $20 \mathrm{mg} / \mathrm{ml}$ bovine serum albumin (BSA, fraction V, Boehringer Mannheim, Laval, PQ, Canada) in HBSS and digested at $37^{\circ} \mathrm{C}$ for $10 \mathrm{~min}$ with continuous shaking. The digest was washed in five changes of HBSS. The residue fractions were examined under a dissecting microscope and clean, intact islets were aspirated by glass pipette from the preparation. The collected islets were washed in Krebs Ringer bicarbonate solution buffered with N-2-hydroxyethylpiperagine-N'-2-ethanesulphuric acid HEPES (KR-HEPES, pH 7.3).

Batches of five islets of comparable size were incubated in $1 \mathrm{ml}$ of KR-HEPES supplemented with $5 \mathrm{mmol} / \mathrm{l}$ sodium pyruvate (Gibco BRL, Burlington, Ont., Canada), $5 \mathrm{mmol} / \mathrm{l}$ sodium fumarate (Sigma Chemical Co.), $5 \mathrm{mmol} / \mathrm{l}$ sodium glutamate (Sigma Chemical Co.), BSA (2 mg/ml) and 1000 kallekrein inhibitor units $\mathrm{KIU} / \mathrm{ml}$ aprotinin (Miles Inc., Kankakee, Ill., USA). Incubations were carried out at $37^{\circ} \mathrm{C}$ in an atmosphere of $\mathrm{O}_{2}: \mathrm{CO}_{2}(95: 5 \%)$ for $30 \mathrm{~min}$ in a shaker (70 stroke/min). Various concentrations of glucose, recombinant IGF-I or II (Upstate Biotechnology Inc., Lake Placid, N. Y., USA) were added to the incubation medium as indicated. Insulin and glucagon levels were measured using radioimmunoassay kits obtained from Pharmacia Canada Inc., (Dorval, PQ, Canada) and Linco Research Inc., (St. Louis, Mo., USA).

Determination of DNA content. The DNA contents of islets were measured using a fluorometric method [11]. Islets were washed with citrate buffer ( $\mathrm{pH} 7.0$ ) in order to remove extracellular calcium and albumin, dried and resuspended in extraction buffer $\left(1 \mathrm{~N} \mathrm{NH}_{4} \mathrm{OH}, 0.2 \%\right.$ Triton $\left.\mathrm{X}-100\right)$. The samples were extracted for $30 \mathrm{~min}$ at $37^{\circ} \mathrm{C}$, diluted with TNE buffer (10 mmol/1 Tris, $1 \mathrm{mmol} / \mathrm{l}$ EDTA, $0.1 \mathrm{~mol} / 1 \mathrm{NaCl}, \mathrm{pH} 7.4$ ), vortexed and centrifuged at $3000 \mathrm{~g}$ for $20 \mathrm{~min}$. The DNA content was measured in a fluorometer (Model TKO 100, Hoefer Scientific Instrument, San Francisco, Calif., USA) using the fluorochrome, Hoechst 33258 (Montreal, Canada) and calf thymus DNA as a standard.

Histochemical analysis of islets. Three $\mathrm{Tg}$ and $\mathrm{Wt}$ mice were killed with an overdose of Avertin and the whole pancreas was carefully dissected out and fixed in $4 \%$ paraformaldehyde in $0.1 \mathrm{~mol} / \mathrm{l}$ phosphate buffer, $\mathrm{pH} 7.4$ for $5 \mathrm{~h}$ at $4{ }^{\circ} \mathrm{C}$ and stored overnight in phosphate buffer containing $20 \%$ sucrose at $4^{\circ} \mathrm{C}$. Frozen sections $8 \mu \mathrm{m}$ thick were cut and mounted on gelatinized slides. In adjacent serial sections, glucagon-, insulin-, somatostatin- and pancreatic polypeptide-containing cells were localized using the avidin-biotin peroxidase complex method. Sections were initially blocked with $4 \%$ normal goat serum (NGS) in phosphate buffer and subsequently incubated for $24 \mathrm{~h}$ at $4{ }^{\circ} \mathrm{C}$ with either guinea pig anti-insulin antisera (1:500 diluted in NGS), rabbit anti-glucagon (1:1000), rabbit anti-somatostatin antisera (1:500) or guinea pig anti-pancreatic polypeptide antisera (1:500). The anti-pancreatic polypeptide antisera was obtained from Linco Research Inc., other antisera were purchased from Incstar Corporation, Stillwater, Min., USA. The antigen-antibody complex was visualized using biotinylated second antibody and avidin-peroxidase (Vector Laboratories Inc., Burlingame, Calif., USA). Sections were examined by light microscopy. The percentage of cells which were positive with each of the antibodies was determined in 10-15 islets from $3 \mathrm{Tg}$ and $\mathrm{Wt}$ mice.

\section{Statistical analysis}

Data are presented as the mean \pm SEM. Significant differences between groups were determined for various parameters using the Student's $t$-test. 


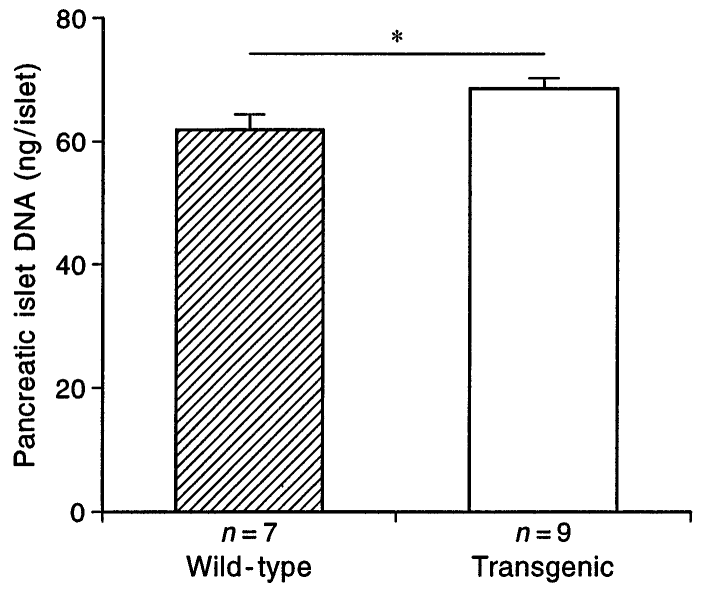

Fig. 1. DNA content in pancreatic islets from wild-type and transgenic mice of the 277A strain. Data represent the mean \pm SEM for the indicated number of separate experiments $* p<0.05$

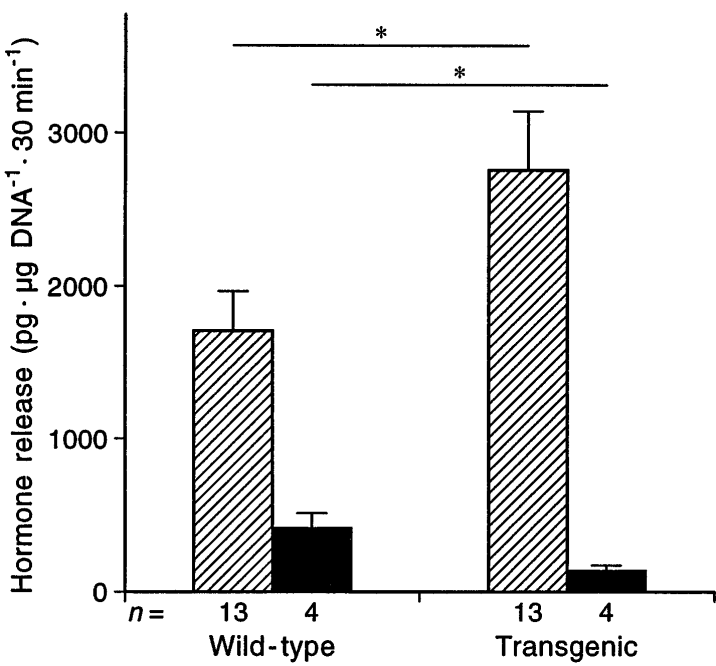

Fig. 2. Insulin $\mathbb{Z}$ and glucagon $\square$ release by islets from wild type and transgenic mice of the 277 A strain. Studies were performed under basal conditions in media containing $3 \mathrm{mmol} / \mathrm{l}$ glucose. Data represent the mean \pm SEM for the indicated number of separate experiments * $p<0.05$

\section{Results}

The Tg mice used in this study demonstrated increased relative weight of the pancreas, and larger and more numerous islets compared to $\mathrm{Wt}$ mice [9]. Consistent with our previous morphometric observation that islet size was increased by approximately $20 \%$, there was an increase in cellularity of the islets as reflected in the increased islet DNA content in $\mathrm{Tg}$ mice compared to Wt mice (Fig. 1). The relative proportion of the different endocrine cell types was determined in islets from $\mathrm{Tg}$ and $\mathrm{Wt}$ mice using immunohistochemical techniques. Islets from $\mathrm{Tg}$ mice contained relatively more beta cells and relatively less alpha cells than $\mathrm{Wt}$ mice (Table 1 ). The relative

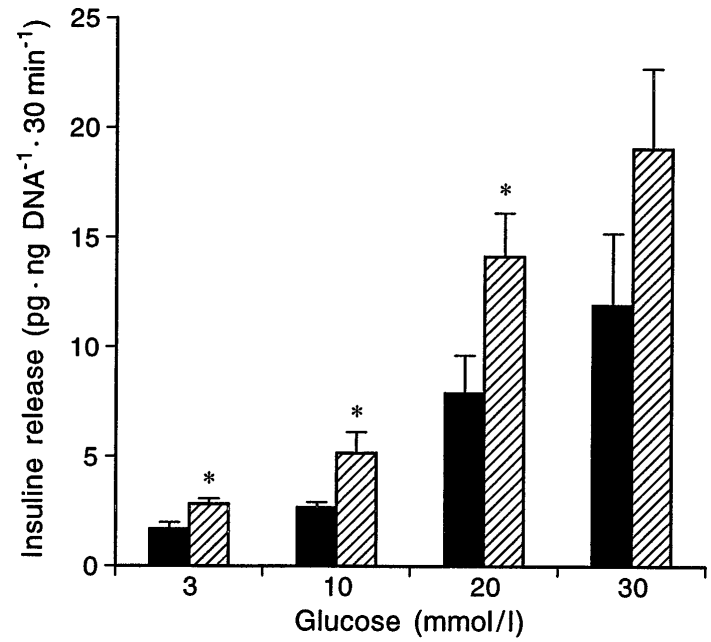

Fig. 3. Glucose-induced insulin release from wild type (Wt $\square$ ) and transgenic $(\mathrm{Tg} \mathbb{Z})$ pancreatic islets. The data represents the mean \pm SEM for five or more separate experiments for each glucose concentration. In each experiment, islets from two Wt or Tg mice were pooled to construct a dose-response curve $* p<0.05$ for the difference between $\mathrm{Wt}$ and $\mathrm{Tg}$ mice

proportions of somatostatin and pancreatic polypeptide staining cells were similar in $\mathrm{Tg}$ and $\mathrm{Wt}$ mice.

To correct for differences in islet cellularity, insulin secretion by islets from $\mathrm{Tg}$ and $\mathrm{Wt}$ mice was expressed per $\mu \mathrm{g}$ of DNA. However, even accounting for the larger size of the islets, islets from $\mathrm{Tg}$ mice released significantly more insulin than islets from $\mathrm{Wt}$ mice (Fig. 2). Similarly the increase in the relative proportion of beta cells in Tg islets, $105 \%$ of the $\mathrm{Wt}$ mice, could not account for the dramatic increase in basal insulin release by $\mathrm{Tg}$ islets (Fig. 2).

Glucagon release by islets from $\mathrm{Tg}$ mice was reduced compared to Wt mice (Fig. 2). A similar inverse relationship was observed in the circulation of fasting Tg mice. Plasma glucagon levels were significantly reduced in $\mathrm{Tg}$ mice compared to $\mathrm{Wt}$ mice $(10.4 \pm 1.0$ vs $15.8 \pm 1.3 \mathrm{pmol} / \mathrm{l} n=6, p<0.01)$. We have previously reported fasting hyperinsulinaemia and hyperglycaemia in Tg mice [9].

The secretion of insulin from isolated pancreatic islets of $\mathrm{Tg}$ and $\mathrm{Wt}$ mice in response to various concentrations of glucose was compared (Fig. 3). A dose-dependent increase in insulin release was observed with increased glucose concentrations in both Wt and Tg mice. At all but the highest glucose concentration, islets from $\mathrm{Tg}$ mice released significantly greater amounts of insulin than islets from Wt mice.

We next determined the effect of IGF-I on islet insulin release. Varying amounts of IGF-I were added to incubations to achieve concentrations ranging from $0.1-10 \mathrm{nmol} / \mathrm{l}$. A dose-dependent increase in insulin release was observed in cultures containing islets from either Tg or Wt mice (Fig. 4A). Under basal conditions where the glucose concentration was $3 \mathrm{mmol} / \mathrm{l}$, the effect of IGF-I on islets from Tg mice 
Table 1. Relative percentage of endocrine cells in islets from transgenic and wild-type mice

\begin{tabular}{lcc}
\hline Cell type & Wild type & Transgenic \\
\hline Beta cells & $75.7 \pm 0.4$ & $79.2 \pm 0.6^{\mathrm{a}}$ \\
Alpha cells & $11.6 \pm 0.5$ & $9.0 \pm 0.4^{\mathrm{b}}$ \\
Delta cells & $7.1 \pm 0.6$ & $7.7 \pm 0.3$ \\
Pancreatic polypeptide cells & $6.3 \pm 0.4$ & $6.5 \pm 0.2$ \\
\hline
\end{tabular}

Data represent the mean \pm SEM for 9 to 15 islets from three mice in each group. ${ }^{\mathrm{a}} p<0.001 ;{ }^{\mathrm{b}} p<0.005$, respectively, for the difference between wild-type and transgenic mice
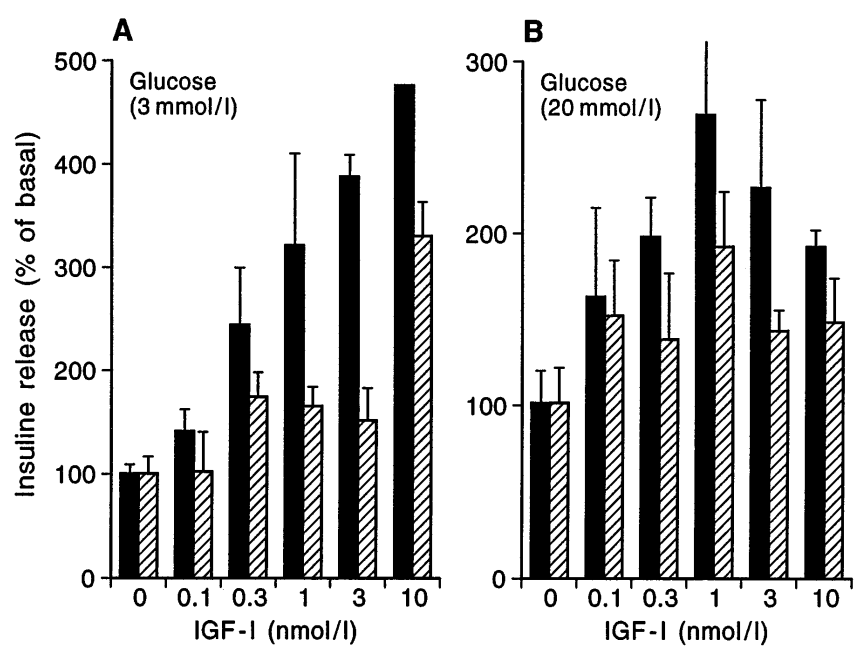

Fig. 4A, B. The effects of IGF-I on insulin release by isolated pancreatic islets from wild type $(\mathrm{Wt})$ or transgenic $(\mathrm{Tg})$ mice. The data represent the mean \pm SEM for four or more separate experiments for each IGF-I concentration. In each experiment islets from two Wt or Tg mice were pooled to construct a doseresponse curve. A data obtained at glucose concentrations of $3 \mathrm{mmol} / \mathrm{l}$ and $\mathbf{B} 20 \mathrm{mmol} / \mathrm{l}$. Insulin release was first corrected for differences in islet size by expressing it as pg of insulin/ng of DNA and was then expressed as a percentage of basal insulin release by islets from Wt $(\square)$ or Tg (ख्A $)$ mice. The absolute values for insulin release at $3 \mathrm{mmol} / \mathrm{l}$ were $1.69 \pm 0.27$ and $2.75 \pm 0.31$ for $\mathrm{Wt}$ and $\mathrm{Tg}$ mice respectively and $2.82 \pm 0.56$ and $4.05 \pm 0.88 \mathrm{Wt}$ and $\mathrm{Tg}$ mice at $20 \mathrm{mmol} / \mathrm{l}$ glucose

was significantly reduced compared to islets from $\mathrm{Wt}$ mice ( $p<0.05$ by analysis of variance). In incubations where the glucose concentration was $20 \mathrm{mmol} / \mathrm{l}$, a biphasic response to IGF-I was seen with higher IGF-I concentrations being less effective than intermediate concentrations. In addition, there was no significant difference in IGF-I response between islets from $\mathrm{Tg}$ and Wt mice (Fig. 4B). These data suggest that IGF-I is less effective in enhancing insulin release when insulin secretion was already stimulated by high glucose concentrations.

The effect of IGF-II on insulin release by islets was also examined. Unlike IGF-I, IGF-II at the concentrations tested had no significant effect on insulin release (Fig. 5).

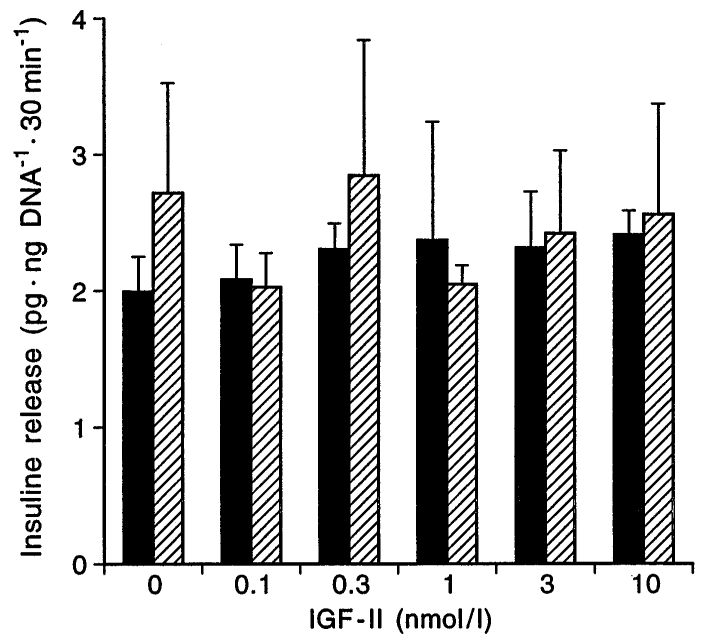

Fig. 5. The effect of IGF-II on insulin release by isolated pancreatic islets from wild type $\square$ or transgenic was added to incubation medium containing $3 \mathrm{mmol} / \mathrm{l}$ glucose. The data represent the mean \pm SEM for four or more separate experiments for each IGF-II concentration

\section{Discussion}

The Tg mice used in this study demonstrated fasting hyperglycaemia, impaired glucose tolerance, reduced pancreatic insulin content and a decline in the insulin to glucose ratio in response to a glucose challenge [9]. Insulin tolerance tests did not demonstrate any difference in insulin sensitivity between $\mathrm{Wt}$ and $\mathrm{Tg}$ mice [9]. This finding suggests that impaired pancreatic insulin secretory function may be important in the aetiology of the glucose intolerance. However, the observations reported here using isolated islets from $\mathrm{Tg}$ mice would not be consistent with this hypothesis. Indeed the islets from Tg mice appeared to be hyper-responsive to glucose and released significantly more insulin at each of the glucose concentrations tested except the highest concentration. Although an increase in islet size and cellularity of the islets from $\mathrm{Tg}$ mice was noted, this alone did not account for the increased insulin release.

There was a small, but significant increase in the relative proportion of beta cells in islets from $\mathrm{Tg}$ mice compared to $\mathrm{Wt}$ mice. Taking into account the $20 \%$ increase in size and cellularity of the Tg islets, this would result in a $25 \%$ increase in the absolute number of beta cells in Tg islets. This is unlikely to be the sole explanation for the $60 \%$ increase in basal insulin release from $\mathrm{Tg}$ islets. The reduced relative proportion of alpha cells in these islets and the reduced glucagon release, could be a potential mechanism underlying the resetting of the glucose coupled insulin release by the Tg islets. Low concentrations of glucagon within the islets would result in enhanced basal insulin release.

The mechanism responsible for the change in the relative ratio of alpha and beta cells in $\mathrm{Tg}$ islets is 
not clear, but presumably results from overexpression of IGFBP-1 during islet neogenesis. Furthermore, continued IGFBP-1 overexpression may have reduced the availability of IGF-I within the islets and potentially reduced the effect of IGF-I on somatostatin release by the delta cells. In the hypothalamus, IGF-I has been shown to increase the somatostatin expression and increase the somatostatin concentration. If a similar mechanism exists in the islets, IGFBP-1 overexpression, by decreasing IGF-I availability, could reduce the local somatostatin content. This could effectively increase the glucose-induced insulin release since the negative effect of somatostatin would be attenuated.

A short negative feedback loop within the islet has also been described whereby insulin inhibits its own release, resulting in low amplitude oscillations in insulin release [12]. It is possible that some degree of insulin resistance at the level of the beta cell could be present in islets from Tg mice accounting for the enhanced glucose-induced insulin release. This seems an unlikely possibility since in previous studies we have demonstrated identical whole body insulin sensitivity in $\mathrm{Tg}$ and $\mathrm{Wt}$ mice [9]. Thus, insulin resistance if present in Tg mice would have to be localized to a few specific tissues.

The transgene, rat IGFBP-1, is expressed at relatively high amounts in islets compared to the adjacent exocrine pancreatic tissue [9]. It is not clear from the studies reported here whether the enhanced glucoseinduced insulin release is a direct result of local expression of IGFBP-1 or the indirect systemic effects of IGFBP-1 overexpression on glucose metabolism. However, if the latter is the case, this systemic effect persists for at least 3-4 h after removal of the islets from the in vivo environment.

Conditioned medium from fetal rat islets contains at least four IGFBPs which on the basis of molecular weight have been considered to represent IGFBP-1, IGFBP-2, IGFBP-3 and IGFBP-4 [13]. Of these, IGFBP-3 is most abundant. Interestingly, in fetal rat islets both glucose and amino acids increased the secretion of these IGFBPs [13]. The functional role of the IGFBPs in islet physiology has not yet been elucidated.

Since at least some initial reports suggested that IGF-I has a suppressive effect on insulin secretion $[14,15]$, we speculated that the enhanced glucose-induced insulin release from $\mathrm{Tg}$ islets was probably a direct result of the inhibition of the suppressive effect of locally expressed IGF-I. To test this hypothesis we examined the effects of exogenous IGF-I on insulin secretion. The data reported here clearly demonstrate that IGF-I stimulates insulin release from isolated murine pancreatic islets. IGF-II was without effect at the concentrations we examined. At these low concentrations, IGF-II would have little effect at the IGF-I receptor. This suggests that the IGF-I effects we observed are likely to be mediated via the IGF-I receptor.

Previous reports in the literature which have addressed the effects of IGF-I on insulin secretion have yielded varied and conflicting data. In vivo studies in various species have consistently shown suppression of pancreatic insulin release $[14,16]$. This effect has been attributed to enhanced glucose disposal and hypoglycaemia induced by IGF-I. However IGF-I receptors are present on pancreatic islet cells [17] and some differences in the glucagon response to hypoglycaemia induced by IGF-I and insulin suggest that IGF-I may have direct suppressive effects on glucagon release by pancreatic alpha cells [18].

In the perfused rat pancreas model, IGF-I suppresses glucose-induced insulin release [19]. A similar suppressive effect is seen with acute exposure of adult rat beta-cell cultures [15]. In contrast IGF-I enhances insulin release when rat islets are incubated for 2-3 days with basal glucose concentrations [20]. The latter effect was not a consequence of enhanced cellular proliferation or cell survival because there was no significant change in DNA content [20]. Furthermore, IGF-I failed to suppress insulin release by cultured human islets, rather a small but non-significant increase in total insulin release was observed [21]. The data reported here using mouse islets would be consistent with these previous longer term studies using rat and human islets. However, the effects of IGF-I on insulin release were attenuated in Tg mouse islets, indicating that the predominant effect of IGFBP-1 over-expression was to inhibit IGF-I action.

In summary a primary defect in pancreatic betacell function is unlikely to be the underlying cause of the glucose intolerance observed in IGFBP-1 Tg mice. Furthermore despite a partial inhibition of the stimulatory effect of IGF-I on insulin secretion, islets from $\mathrm{Tg}$ mice secrete more insulin at lower glucose concentrations than the Wt mice. Further studies are required to determine whether this phenomenon is a consequence of the hyperglycaemia that occurs in the $\mathrm{Tg}$ mice or a direct result of overexpression of IGFBP-1 in the islets.

Acknowledgements. This research was supported by grants from the Canadian Diabetes Association, Medical Research Council of Canada and from the H.E. Sellers Fund. S. T. D. is a recipient of a CDA postdoctoral fellowship. L. J.M. is a recipient of an MRC Scientist award and an endowed Research Professorship in Metabolic Diseases.

\section{References}

1. McCusker RH, Clemmons DR (1992) The insulin-like growth factor binding proteins: structure and biological functions. In: Schofield PN (ed) The insulin-like growth factors, structure and biological functions. Oxford University Press, Oxford pp 110-150 
2. Clemmons DR (1990) Insulin-like growth factor binding proteins. Trends Endocrinol Metab 1: 412-417

3. Lewitt MS, Baxter RC (1991) Insulin-like growth factor binding protein-1: a role in glucose counterregulation? Mol Cell Endocrinol 79:C147-C152

4. Lewitt MS, Denyer GS, Cooney GJ Baxter RC (1991) Insulin-like growth factor binding protein-1 modulates blood glucose levels. Endocrinology 129: 2254-2259

5. Murphy LJ, Seneviratne C, Moreira P, Reid R (1991)Enhanced expression of insulin-like growth factor binding protein-1 in the fasted rat: the effects of insulin and growth hormone administration. Endocrinology 128: 689-696

6. Baxter RC, Cowell CT (1987) Diurnal rhythm of growth hormone-independent binding protein for insulin-like growth factors in human plasma. J Clin Endocrinol Metab 65: 432-440

7. Suwanickul A, Morris SL, Powell DR (1993) Identification of an insulin-responsive element in the promoter of the human gene for insulin-like growth factor binding protein-1. J Biol Chem 268: 17063-17068

8. Rajkumar K, Barron D, Lewitt MS, Murphy LJ (1995) Growth retardation and hyperglycaemia in insulin-like growth factor binding protein-1 transgenic mice. Endocrinology 136: 4029-4034

9. Rajkumar K, Dheen ST, Murphy LJ (1996) Hyperglycaemia and impaired glucose tolerance in insulin-like growth factor binding protein-1 transgenic mice. Am J Physiol 270:E565-E571

10. Lacy PE, Kostianovsky M (1967) Method for the isolation of intact islets of Langerhans from the rat pancreas. Diabetes 6: 35-39

11. Downs TR, Wilfinger WW (1983) Fluorometric quantification of DNA in cells and tissue. Anal Biochem 131: 538547

12. Bergsten P (1995) Slow and fast oscillations of cytoplasmic $\mathrm{Ca}^{2+}$ in pancreatic islets correspond to pulsatile insulin release. Am J Physiol 268:E282-E287
13. Hogg J, Han VKM, Clemmons DR, Hill DJ (1993) Interactions of nutrients, insulin-like growth factors (IGFs) and IGF-binding proteins in the regulation of DNA synthesis by isolated fetal rat islets of Langerhans. J Endocrinol 138: 410-412

14. Zenobi PD, Graf S, Ursprung H, Froesch ER (1992) Effects of insulin-like growth factor-I on glucose tolerance, insulin levels and insulin secretion. J Clin Invest 89: 1908-1913

15. Van Schravendijk CFH, Heylen L, Van der Brande JL, Pipeleers DG (1990) Direct effect of insulin and insulinlike growth factor-I on the secretory activity of rat pancreatic beta cells. Diabetologia 121: 1784-1788

16. Kolaczynski JW, Caro JF (1994) Insulin-like growth factor I therapy for diabetes mellitus? Diabetes Care 17: 92-96

17. Van Schravendijk CFH, Foriers A, Van der Brande JL, Pipeleers DG (1990) Evidence for the presence of type 1 insulin-like growth factor receptor on rat pancreatic beta cells. Diabetologia 33: 649-653

18. Kerr D, Tamborlane WV, Rife, F, Sherwin RS (1993) Effect of insulin-like growth factor-I on the responses to and recognition of hypoglycemia in humans: a comparison with insulin. J Clin Invest 91: 141-147

19. Leahy JL, Vanderkerhove KM (1990) Insulin-like growth factor-I at physiological concentrations is a potent inhibitor of insulin secretion. Endocrinology 126: 1593-1598

20. Sieradzki J, Fleck H, Chatterjee AK, Schatz H (1988) Stimulatory effects of insulin-like growth factor-I on $\left[{ }^{3} \mathrm{H}\right]$ thymidine incorporation, DNA content and insulin biosynthesis and secretion of isolated pancreatic rat islets. $\mathrm{J}$ Endocrinol 177: 59-62

21. Eizirik DL, Skottner A, Hellerstrom C (1995) Insulin-like growth factor I does not inhibit insulin secretion in adult human pancreatic islets in tissue culture. Eur J Endocrinol 133: $248-250$ 